\title{
Acute Kidney Injury: From Diagnosis to Prevention and Treatment Strategies
}

\author{
Joana Gameiro * ${ }^{\mathbb{C}}$, José Agapito Fonseca ${ }^{\circledR}$, Cristina Outerelo and José António Lopes $(\mathbb{D}$ \\ Department of Medicine, Division of Nephrology and Renal Transplantation, Centro Hospitalar Lisboa Norte, \\ EPE, Av. Prof. Egas Moniz, 1649-035 Lisboa, Portugal; jose.nuno.agapito@gmail.com (J.A.F.); \\ cristinaouterelo@gmail.com (C.O.); jalopes93@hotmail.com (J.A.L.) \\ * Correspondence: joana.estrelagameiro@gmail.com; Tel.: +351-21-780-5000
}

Received: 23 April 2020; Accepted: 25 May 2020; Published: 2 June 2020

\begin{abstract}
Acute kidney injury (AKI) is characterized by an acute decrease in renal function that can be multifactorial in its origin and is associated with complex pathophysiological mechanisms. In the short term, AKI is associated with an increased length of hospital stay, health care costs, and in-hospital mortality, and its impact extends into the long term, with AKI being associated with increased risks of cardiovascular events, progression to chronic kidney disease (CKD), and long-term mortality. Given the impact of the prognosis of AKI, it is important to recognize at-risk patients and improve preventive, diagnostic, and therapy strategies. The authors provide a comprehensive review on available diagnostic, preventive, and treatment strategies for AKI.
\end{abstract}

Keywords: acute kidney injury; prevention; diagnosis; treatment

\section{Introduction}

Acute kidney injury (AKI) is a frequent diagnosis with an incidence that varies from $5.0 \%$ to $7.5 \%$ in hospitalized patients and that reaches up to $50-60 \%$ in critically ill patients [1-6]. AKI is characterized by an acute decrease in renal function that can be multifactorial in its origin and is associated with complex pathophysiological mechanisms [1,7].

In the short term, AKI is associated with an increased length of hospital stay, health care costs, and in-hospital mortality, and its impact extends into the long term, with AKI being associated with increased risks of cardiovascular events, progression to chronic kidney disease (CKD), and long-term mortality [8].

The incidence of AKI has increased in the past few decades, which might reflect the impact of the increased recognition of this diagnosis and improvements in patient care, namely through improvements in dialytic care, the availability of less nephrotoxic drugs, and a decrease in the use of dopamine and diuretics [1,9]. Mortality rates have declined in critically ill patients with AKI, but mortality rates are still significantly high and increase with AKI severity, specifically in dialysis-requiring AKI [6,9-11].

AKI survivors are at increased risk of developing CKD, which defined by the persistence of kidney disease for a period of more than 90 days [8]. Additionally, investigators now consider that AKI and CKD are part of a disease continuum instead of separate entities [8]. Indeed, the term acute kidney disease (AKD) has been recently proposed to define the continuing pathological processes and adverse events developing after AKI [12].

AKD is defined as an acute or subacute damage and/or a loss of kidney function for a duration of between 7 and 90 days after exposure to an AKI-initiating event [12]. This highlights the importance of renal recovery, as recovery within $48 \mathrm{~h}$ is typically associated with the rapid reversal of AKI, as well as the impact of AKD on pre-existing CKD in increasing the risk for kidney disease progression [12]. 
Given the impact of the prognosis of AKI, it is important to enhance the recognition of at-risk patients and to improve preventive, diagnostic, and therapeutic strategies. The authors provide a comprehensive literature review on available preventive and therapeutic strategies for AKI.

\section{Diagnosis of AKI}

The currently widespread AKI classification was developed by the Kidney Disease Improving Global Outcomes (KDIGO) work group in 2012 and defines AKI as an increase in the serum creatinine (SCr) level to at least $0.3 \mathrm{mg} / \mathrm{dL}$ within $48 \mathrm{~h}$, an increase in $\mathrm{SCr}$ to more than 1.5 times the baseline (which is known or presumed to have occurred within the prior 7 days), or a urine output (UO) decrease to less than $0.5 \mathrm{~mL} / \mathrm{kg} / \mathrm{h}$ for $6 \mathrm{~h}$ [13]. This classification also stratifies different stages of AKI severity and provides criteria that could be applied in clinical activity and investigation [14] (Table 1).

Table 1. Kidney Disease Improving Global Outcomes (KDIGO) classification.

\begin{tabular}{ccc}
\hline Stage & SCr & UO \\
\hline 1 & $\begin{array}{c}\text { Increase in } \mathrm{SCr} \geq 0.3 \mathrm{mg} / \mathrm{dL}(\geq 26.5 \mu \mathrm{mol} / \mathrm{L}) \text { or } \\
\text { increase in } \mathrm{SCr} \geq 150 \% \text { to } 200 \%(1.5 \text { to } 1.9 \mathrm{X})\end{array}$ & $<0.5 \mathrm{~mL} / \mathrm{kg} / \mathrm{h}(>6 \mathrm{~h})$ \\
\hline 2 & Increase in $\mathrm{SCr}>200 \%$ to $300 \%$ ( $>2$ to $2.9 \mathrm{X})$ & $<0.5 \mathrm{~mL} / \mathrm{kg} / \mathrm{h}(>12 \mathrm{~h})$ \\
\hline 3 & $\begin{array}{c}\text { Increase in } \mathrm{SCr}>300 \%(\geq 3 \mathrm{X}) \text { or Increase in } \\
\text { SCr to } \geq 4 \mathrm{mg} / \mathrm{dL}(\geq 353.6 \mu \mathrm{mol} / \mathrm{L}) \text { or initiation } \\
\text { of renal replacement therapy }\end{array}$ & $<0.3 \mathrm{~mL} / \mathrm{kg} / \mathrm{h}(24 \mathrm{~h})$ or anuria $(12 \mathrm{~h})$ \\
\hline \multicolumn{3}{c}{ SCr: serum creatinine; UO: urine output. }
\end{tabular}

The current definition relies on $\mathrm{SCr}$ and UO, which are imperfect markers with significant limitations, namely that these do not account for the duration or cause of AKI [15]. SCr is an insensitive marker because it is altered by factors affecting its production (age, gender, diet, muscle mass, and sepsis), dilution (fluid administration), elimination (previous renal dysfunction), and secretion (medications). Thus, $\mathrm{SCr}$ cannot be used as an accurate estimate of glomerular filtration rate (GFR) in the non-steady state, and it underestimates the degree of dysfunction due to reduced muscle mass, increased catabolism, or positive fluid balance in critical patients. Additionally, it often takes two-to-three days before SCr is elevated after a renal insult when renal injury occurs in the setting of appropriate renal reserve, meaning that other nephrons increase function to compensate for injured nephrons, and so SCr may not change despite actual structural damage [16,17].

Though UO is an early marker for AKI, it also relies on patient's volemic and hemodynamic status and the use of diuretics, and so it is difficult to assess without a urinary catheter and its usefulness relies on an hourly assessment that is time consuming $[15,17,18]$.

Recently, potential urinary and serum biomarkers of AKI have been identified, namely cystatin-C, neutrophil gelatinase associated lipocalin (NGAL), N-acetyl-glucosaminidase (NAG), kidney injury molecule 1 (KIM-1), interleukin-6 (IL-6), interleukin-8 (IL-8), interleukin 18 (IL-18), liver-type fatty acid-binding protein (L-FABP), calprotectin, urine angiotensinogen (AGT), urine microRNAs, insulin-like growth factor-binding protein 7 (IGFBP7), and tissue inhibitor of metalloproteinases-2 (TIMP-2) [19-29]. Both NGAL and IGFBP7 with TIMP-2 are the most promising markers that have been validated in multiple settings. However, their increased cost and a lack of substantial evidence of improvement of outcomes are important limitations for their widespread clinical use [30,31].

These markers reflect different stages of the pathophysiology of AKI, so, the use of a panel of several biomarkers covering different phases of this syndrome might provide a better early diagnostic tool for AKI, as well as providing targets for future treatments [27,28,30,32-35].

\section{Risk factors for AKI}

Both patient susceptibilities and exposures are risk factors for AKI [11,36,37] (Table 2). 
Patient age is an important non-modifiable risk factor, as the loss of renal reserve and the physiologic decline of GFR may place older patients at risk for AKI [38-42].

CKD patients possess a loss of autoregulation, abnormal vasodilation, susceptibility to antihypertensive agents, and nephrotoxins, and the side effects of medication contribute to the development of AKI [42]. Moreover, AKI and CKD have been described as interconnected syndromes because AKI leads to the worsening of CKD and CKD predisposes one to AKI [42,43]. CKD also limits renal recovery after AKI [44].

Patient comorbidities such as diabetes mellitus, hypertension, cardiovascular disease, chronic liver disease, and chronic obstructive pulmonary disease have also been identified as important AKI predictors $[11,13,36,37,40,45,46]$. Given the increasing incidence of HIV-infected patients in past few decades, HIV infection is also a risk factor that predisposes patients to AKI [47,48].

Exposure to sepsis, surgery, nephrotoxins, and shock are specific modifiable factors that contribute to AKI $[1,13]$. Indeed, large cohort studies focusing on critically ill patients have reported that the two most important causes of AKI are sepsis and surgery [6,49].

Additionally, recent research has reported that other factors like hyperuricemia, hypoalbuminemia, obesity, anemia, and hyperglycemia have been associated with an increased risk of AKI [49-69].

Table 2. Risk factors for acute kidney injury (AKI).

\begin{tabular}{cc}
\hline \multicolumn{1}{c}{ AKI Risk Factors } \\
\hline Older age & Shock \\
Diabetes & Sepsis \\
Hypertension & Nephrotoxins \\
Chronic kidney disease & (NSAIDs, ARB, ACEi, contrast) \\
Cardiovascular disease & Surgery \\
Chronic liver disease & Hyperuricemia \\
Chronic obstructive pulmonary disease & Hypoalbuminemia \\
HIV infection & Hyperglycemia \\
Obesity & Anemia \\
\hline
\end{tabular}

ACEi: angiotensin-converting enzyme inhibitor; ARB: angiotensin receptor blocker; NSAID: nonsteroidal anti-inflammatory drugs.

\section{Causes and Assessment of AKI}

AKI is a complex syndrome involving numerous pathophysiological processes that include pre-renal AKI, acute tubular necrosis, acute interstitial nephritis, acute glomerular diseases, and acute obstructive nephropathy [54].

These causes can be systematized into three groups, namely prerenal AKI, which accounts for up to $60 \%$ of cases and results from the functional adaptation to hypoperfusion of structurally normal kidneys; intrinsic renal AKI, which results from structural damage to any component of the renal parenchyma and accounts for up to $40 \%$ of cases; and, less frequently, postrenal AKI, which results from urinary tract obstruction $[55,56]$. The causes are summarized in Table 3.

Essentially, the majority of causes of AKI are actually not renal-specific because the kidneys are highly sensitive to any systemic upset [55]. Indeed, the most common causes being septic shock, post major surgery, cardiogenic shock, and hypovolemia highlight this fact [57].

Most cases are multifactorial, and, following the inciting event causing kidney injury, numerous pathophysiologic pathways occur, including hemodynamic instability, microcirculatory dysfunction, tubular cell injury, tubular obstruction, renal congestion, microvascular thrombi, endothelial dysfunction, and inflammation $[55,56,58-60]$.

The assessment of the cause of AKI must include a careful history, including medications and exposures, as well as a thorough physical examination. The assessment of fluid status and the presence of signs and symptoms of acute or chronic heart failure, infection, and urinary tract obstruction must be included in a first approach $[54,61]$. 
Table 3. Causes of AKI.

\begin{tabular}{|c|c|c|}
\hline \multicolumn{3}{|c|}{ Causes of AKI } \\
\hline Pre-renal & Intrinsic & Post-renal \\
\hline & - Tubular & \multirow{16}{*}{$\begin{array}{c}\text { - Extrarenal obstruction } \\
\text { Prostate hypertrophy } \\
\text { Improperly placed catheter } \\
\text { Bladder, prostate or cervical cancer } \\
\text { Retroperitoneal fibrosis }\end{array}$} \\
\hline & Renal ischemia & \\
\hline - Hypovolemia & (shock, surgery, hemorrhage, trauma, & \\
\hline Hemorrhage & bacteremia, pancreatitis, pregnancy) & \\
\hline Volume depletion & Nephrotoxic drugs & \\
\hline Renal fluid loss (over-diuresis) & (antibiotics, antineoplastic drugs, & \\
\hline $\begin{array}{c}\text { Third space (burns, peritonitis, } \\
\text { muscle trauma }\end{array}$ & $\begin{array}{l}\text { contrast media, organic solvents, } \\
\text { anesthetic drugs, heavy metals) }\end{array}$ & \\
\hline & Endogenous toxins & \\
\hline & (myoglobin, hemoglobin, uric acid) & \\
\hline \multirow{7}{*}{$\begin{array}{l}\text { - Impaired cardiac function } \\
\text { Congestive heart failure } \\
\text { Acute myocardial infarction } \\
\text { Massive pulmonary embolism }\end{array}$} & - Glomerular & \\
\hline & Post-infectious glomerulonephritis & \\
\hline & Lupus nephritis & \\
\hline & IgA glomerulonephritis & \\
\hline & Infective endocarditis & \\
\hline & Goodpasture syndrome & \\
\hline & Wegener disease & \\
\hline - Systemic vasodilatation & - Interstitial & \multirow{14}{*}{$\begin{array}{c}\text { - Intrarenal obstruction } \\
\text { Nephrolithiasis } \\
\text { Blood clots } \\
\text { Papillary necrosis } \\
\text { Drugs (acyclovir, methotrexate) }\end{array}$} \\
\hline Anti-hypertensive medications & Infections & \\
\hline Gram negative bacteremia & (bacterial, viral) & \\
\hline Cirrhosis & Medications(antibiotics, diuretics, & \\
\hline Anaphylaxis & NSAIDs, anti-ulcer agents) & \\
\hline \multirow{9}{*}{$\begin{array}{c}\text { - Increased vascular resistance } \\
\text { Anesthesia } \\
\text { Surgery } \\
\text { Hepatorenal syndrome } \\
\text { NSAID medications } \\
\text { Drugs that cause renal } \\
\text { vasoconstriction (cyclosporine, } \\
\text { ARB, ACEi) }\end{array}$} & - Vascular & \\
\hline & Large vessels & \\
\hline & (bilateral renal artery stenosis, & \\
\hline & bilateral renal vein thrombosis) & \\
\hline & Small vessels & \\
\hline & (vasculitis, malignant hypertension, & \\
\hline & atherosclerotic or thrombotic emboli, & \\
\hline & hemolytic uremic syndrome, & \\
\hline & $\begin{array}{l}\text { thrombotic thrombocytopenic } \\
\text { purpura) }\end{array}$ & \\
\hline
\end{tabular}

IgA: Immunoglobulin A.

Laboratory evaluation should comprise SCr, urea, electrolytes, complete blood count, liver function tests, glucose level, bone profile, urine analysis, and microscopic examination, and a renal ultrasound must be performed to exclude obstruction. Urine output should be measured. A chest $\mathrm{x}$-ray can provide evidence of a potential cause, such as pneumonia or vasculitis, but it can also prove useful in volume overload evaluation [54,61].

Less frequent causes of AKI such as vasculitis, glomerulopathy, and hemolytic uremic syndrome should be considered in the presence of fever, rash, joint pains, pulmonary infiltrates, abnormal urine analysis, thrombocytopenia, and hemolytic anemia when significant dehydration, hypotension, nephrotoxins, and obstruction have been excluded [54,61]. Thus, the determination of the cause of AKI must be completed with an assessment of antineutrophil cytoplasmic antibodies (ANCA), anti-glomerular basement membrane antibodies (anti-GBM), antinuclear antibodies (ANA), anti-double stranded DNA (anti-dsDNA) antibodies, complement factors, rheumatoid factor, antistreptolysin O titer (ASOT), cryoglobulins, serum electrophoresis, immunoglobulins, serum free light chains, hepatitis, and HIV serology [54,61] (Table 4). 
Table 4. Preventive and treatment strategies for AKI.

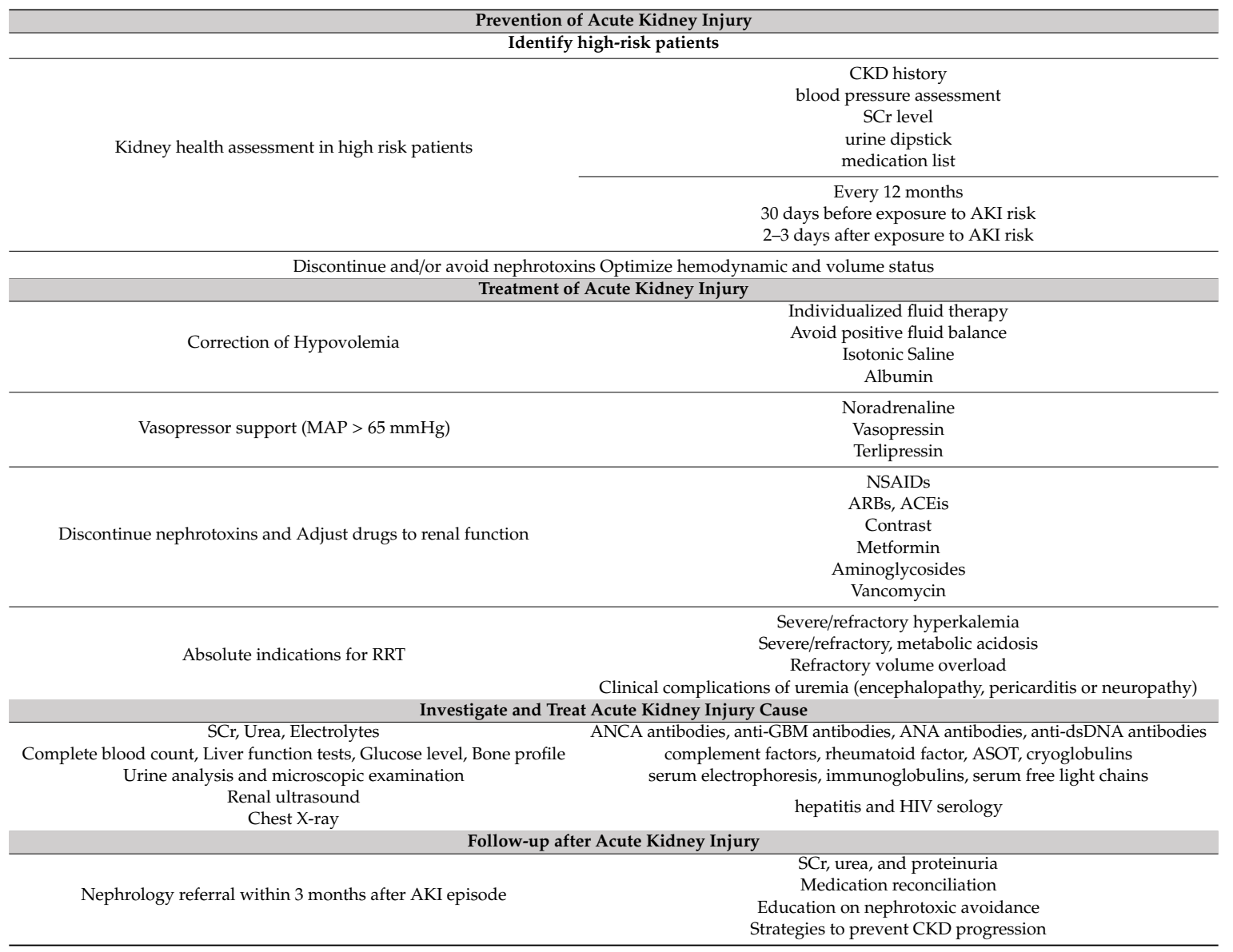

ANA: antinuclear antibodies; ANCA: antineutrophil cytoplasmic antibodies; anti-GBM: anti-glomerular basement membrane; anti-dsDNA: anti-double stranded DNA; ARB: angiotensin receptor blocker; ASOT: antistreptolysin O titer; CKD: chronic kidney disease; RRT: renal replacement therapy.

\section{Treatment of AKI}

The therapeutic strategies for AKI based on the KDIGO guidelines and bundles of care are limited and mostly supportive [13].

The clinical approach should begin by hemodynamic stabilization, the early identification of complications of AKI, the identification of its cause, and its treatment [62]. Hemodynamic stabilization is of critical significance because autoregulation mechanisms are impaired in AKI [63].

Particular attention should be given to medications with renal toxicity, which should be discontinued, and dose adjustment according to renal function to avoid underdosing or adverse effects [62,64]. Additionally, in septic patients, prompt initiation of antibiotics is crucial [65].

It is important to rapidly identify and treat other complications in the therapeutic approach for the patient with AKI, such as hyperkalemia, metabolic acidosis, anemia, and fluid overload [13].

During the course of AKI, it is also recommended to prevent infection and start stress-ulcer prophylaxis [13].

\subsection{Fluid Therapy}

Fluid balance should be individualized, although the optimal fluid to this effect is undetermined. The titration of fluids is complex and requires the careful monitoring of patient's volemia [63]. Hypovolemia reduces renal blood flow, but AKI patients are also at risk for volume overload [55]. Furthermore, a positive fluid balance is independently associated with increased mortality in AKI 
patients and contributes to worse outcomes in critically ill patients [66-68]. Goal-directed therapy guided by the assessment of fluid responsiveness appears to be associated with better outcomes $[69,70]$.

Different types of fluids have different mechanisms of action. While colloids, such as albumin or starches, rely on oncotic gradients and selectively expand the extracellular space, crystalloids-namely saline, Ringer's lactate or PlasmaLyte-equilibrate across intravascular and extravascular spaces [63,71].

Albumin appears to be relatively safe, but a consistent survival advantage compared with crystalloids has not been demonstrated [72-74]. The Saline Versus Albumin Fluid Evaluation (SAFE) trial reported that there was no renal or mortality benefit in patients who received albumin, but less total volume was required for resuscitation, which could be attractive in reducing positive fluid balance [72]. Furthermore, in the Colloids Versus Crystalloids for the Resuscitation of the Critically Ill (CRISTAL) trial, there was a decrease in need for mechanical ventilation, the need for vasopressors, and the mortality at 90-days in patients who received colloids [75].

Thus, albumin may prove important when large volumes of fluids are anticipated. Indeed, the recent Surviving Sepsis Campaign recommendations state that when patients require substantial amounts of crystalloids, albumin might be additionally used [76]. Still, there are no data supporting the routine use of colloids for volume resuscitation [77].

The administration of albumin in combination with terlipressin is also beneficial in specific conditions, such as cirrhotic patients and cardiac surgery patients with hypoalbuminemia in which the preoperative administration of albumin reduces the risk of postoperative AKI [78,79]. Nevertheless, caution must be taken in patients with traumatic brain injury, in which albumin has been associated with an increased mortality risk and should be avoided [72]. Some concerns have been raised on the use of hyperoncotic albumin in septic shock patients who are volume depleted and have increased vascular permeability, as it might increase AKI risk by promoting intracellular dehydration to expand volume [80,81].

Large randomized trials have reported higher incidences of AKI in patients treated with starches, which appears to be due to osmotic nephrosis with proximal tubule vacuolization and swelling. [63,82,83] The use of starches should thus be avoided [82].

There are less data concerning the use of gelatins and AKI, though observational data suggest these might contribute to AKI due to osmotic nephrosis [84]. Therefore, the use of gelatins is also not recommended in AKI [13,63].

Saline is the most frequently used crystalloid in critically ill patients $[63,85]$. Nevertheless, the administration of large volumes can cause hyperchloremia and metabolic acidosis. Hyperchloremia can lead to renal vasoconstriction and a consequent reduction in glomerular filtration $[71,86]$.

Studies comparing different types of crystalloids in critically ill patients at risk of AKI have demonstrated conflicting results [85-89]. Yunos reported that a chloride-restrictive strategy was associated with a significant decrease in the incidence of AKI in critically ill patients [88]. The Saline versus PlasmaLyte for intensive care unit (ICU) Fluid Therapy (SPLIT) trial did not find differences in the rates of AKI or mortality in a population of mostly postoperative patients who received modest volumes for resuscitation [90,91]. In the Isotonic Solutions and Major Adverse Renal Events Trial (SMART) and in the Saline against Lactated Ringer's or PlasmaLyte in the Emergency Department (SALT-ED), trial there were reductions in adverse kidney outcomes within 30 days in patients who received buffered solutions [85,92]. Though it is theorized that AKI occurs due to hyperchloremia only when large volumes are administered, a recent study of critically ill patients receiving large volumes of fluid did not demonstrate an association between chloride load and AKI risk after adjusting for disease severity [93]. Thus, saline remains the preferred solution for volume resuscitation, though chloride concentrations should be monitored [13,55,62].

\subsection{Vasopressor Drugs}

After volume resuscitation, vasopressor support should be considered to maintain renal perfusion in order to avoid positive fluid balance. In patients with AKI, the median blood pressure target should be higher than $65 \mathrm{mmHg}$ to ensure accurate renal perfusion $[13,94-96]$. 
In vasodilatory states, noradrenaline is the recommended first-line vasopressor $[76,97]$. Noradrenaline improves microcirculatory flow by increasing perfusion pressure above the autoregulation threshold in hypotensive patients, but in high doses, it can cause a decrease in the flow by excessive vasoconstriction [98]. Thus, the current recommendations suggest to administer the lowest dose to achieve the blood pressure target and keep adequate perfusion parameters [98].

Vasopressin and terlipressin are effective alternatives for raising blood pressure, though their benefit on kidney function or mortality comparing to noradrenaline has not been demonstrated [99-102]. Angiotensin II has shown promising results on patient outcomes in recent studies, namely by improving survival and renal function recovery [103]. Nevertheless, further studies are still required to recommend the routine use of angiotensin II.

In contrary to previous beliefs, there is no evidence for a "renal dose" dopamine in AKI management, because there is no association between dopamine use in AKI and improvement in survival or renal function [104-107]. Fenoldopam has a similar hemodynamic renal effect to that oe low-dose dopamine and had been demonstrated to decrease systemic vascular resistance whilst increasing renal blood flow to the kidney $[108,109]$. Despite promising studies, there has been no conclusive evidence of the beneficial effect of fenoldopam in the management of AKI, and further investigation is warranted [110,111].

\subsection{Diuretics}

The use of diuretics is only recommended to manage fluid overload and electrolyte disturbances in AKI $[13,112]$. Based on pathophysiology studies, it was previously thought that loop diuretics might protect the loop of Henle from ischemia by decreasing its workload [112]. This has never been confirmed, and, on the contrary, it has been demonstrated that furosemide is not associated with clinical benefits in preventing AKI, decreasing the need for renal replacement therapy (RRT), renal recovery, or decreasing in-hospital mortality [113-115]. It is important to note that certain studies have associated the use of loop diuretics with an increased risk of mortality, which might be related to the delay in appropriate RRT start $[112,115,116]$. Additionally, a loop diuretic used in high doses may cause ototoxicity [112]. Therefore, the KDIGO guidelines do not recommend the use of diuretics to prevent AKI [13].

\subsection{Drug Nephrotoxicity}

Drug nephrotoxicity has been associated with $20-40 \%$ of AKI causes and can reach up to $60 \%$ in elderly patients $[117,118]$. Patients with underlying AKI or CKD, sepsis, acute or chronic liver failure, acute or chronic heart failure, pulmonary hypertension, malignancies, and exposure surgery are at increased risk for drug-induced nephrotoxicity [117].

The mechanisms of drug-induced nephrotoxicity are diverse and vary with different drug classes. (Table 3). Drugs can induce not only direct toxicity due to tubular injury, interstitial nephritis, glomerular injury, or obstructive nephropathy but also indirect nephrotoxicity associated with a decrease in renal blood flow [119]. Furthermore, drug-induced nephrotoxicity results from the combination of innate drug toxicity, altered renal hemodynamics, previous renal disease, and altered drug pharmacokinetics in critical illness $[119,120]$.

Due to the associated reduced glomerular pressure, patients exposed to nonsteroidal anti-inflammatory drugs (NSAIDs), renin-angiotensin-aldosterone system blockers, high-dose systemic vasoconstrictors, or calcineurin inhibitors are at high-risk to develop prerenal AKI in the setting of altered systemic and renal hemodynamics or fluid loss; these also increase the risk for acute tubular injury [117].

Acute tubular necrosis (ATN) is dose-dependent and is the most common form of drug-induced AKI in the hospital setting [121]. The most common drugs associated with ATN are aminoglycosides, vancomycin, radiocontrast media, cisplatin, amphotericin B, foscarnet, and osmotically active agents [117,121].

Acute interstitial nephritis (AIN) causes up to $10 \%$ of AKI cases. AIN is an idiosyncratic reaction that is not dose-dependent $[117,120]$. Antimicrobials such as b-lactams, sulfa-based drugs and 
quinolones, anti-ulcer agents, anti-convulsants, and diuretics are the most common drugs associated with AIN $[117,118,122]$.

Post-renal AKI due to crystal-induced luminal obstruction can occur in patients exposed to acyclovir, sulfa-based medications, ciprofloxacin, and methotrexate [121]. Less frequently, drug-induced glomerular disease can result from the administration of hydralazine, propylthiouracil, allopurinol, and penicillamine, all of which have been associated with development of ANCA vasculitis, mitomycin $\mathrm{C}$, oral contraceptive agents, calcineurin inhibitors, antineoplastic agents, ticlopidine, and quinine, all of which can cause thrombotic microangiopathy [121].

Therefore, the prescription of drugs must be carefully considered to minimize toxicity. The KDIGO guidelines recommend the early discontinuation of potential nephrotoxic drugs, the avoidance of radiocontrast and other nephrotoxic drugs, and drug dose monitoring [13].

\subsection{Other Therapeutic Strategies}

Remote ischemic preconditioning is a technique that induces multiple short cycles of ischemia and reperfusion by cuff inflation [123]. This has been tested as a possible method to protect the kidneys from ischemia reperfusion injury, although there is conflicting evidence regarding the results in reducing AKI or mortality, and it is not recommended in clinical practice [124-128].

Levosimendan has both vasodilatory and inotropic actions [129]. It might improve kidney function by improving cardiac function but also through afferent arteriolar vasodilatation, though this benefit remains debatable [130]. In a recent meta-analysis, the use of levosimendan was associated with a decrease in AKI incidence and mortality in cardiac surgery patients, proving its potential use [131].

Several new potential therapeutic targets for AKI are currently being investigated and entering clinical trials. These include pathways involved in inflammation, fibrosis, mitochondrial function, oxidative stress, and hemodynamics. Though promising, further clinical trials are still required.

Reltecimod is a peptide antagonist of CD28 (co-stimulatory receptor) that acts as an immunomodulator and has been demonstrated to attenuate the systemic inflammatory response and decrease organ dysfunction in necrotizing soft tissue infections [132,133].

Due to the fact that active vitamin D has anti-proliferative and pro-differentiation actions, it might be that lower levels of vitamin D contribute to AKI $[134,135]$. Indeed, critically ill patients with vitamin D deficiencies have been reported to have higher rates of AKI and further progression to CKD [135-137]. Calcifediol and calcitriol are still under investigation as possible treatments in early AKI [138-140].

Alkaline phosphatase is an enzyme expressed along the proximal tubule and has the ability to reduce renal inflammation. The use of human recombinant alkaline phosphatase has been investigated in clinical trials as a potential anti-inflammatory drug that could attenuate kidney injury or promote renal regeneration [141-143]. A recent trial reported that, despite not affecting short-term kidney function, there was a long-term benefit in kidney function [144].

Teprasiran is under investigation as an apoptosis inhibitor and has had promising results in patients undergoing cardiac surgery at risk for AKI by demonstrating a reduction in major adverse kidney events at 90 days $[145,146]$.

Intensive investigation in this area reflects the fact that, to date, there are no established pharmacotherapies for AKI. The most important measures to be applied in clinical practice remain the hemodynamic monitoring and administration of fluids and vasopressors, the eviction and avoidance of nephrotoxins, and the treatment of AKI complications (Table 4).

\subsection{Renal Replacement Therapy}

Conventional criteria for initiation of RRT in AKI are anuria, severe/refractory hyperkalemia, severe/refractory metabolic acidosis, refractory volume overload, severe azotemia, or clinical complications of uremia such as encephalopathy, pericarditis, or neuropathy [147,148].

There are different modalities of RRT that can be provided in cases of severe AKI, namely intermittent hemodialysis (HD), continuous RRT (CRRT), slow low-efficiency dialysis (SLED), or peritoneal dialysis 
(PD) [149]. Continuous RRT (CRRT) is the most common form of renal support provided to critically ill patients because it provides better volume control and acid-base and electrolyte correction while maintaining hemodynamic stability $[147,148]$. Though there is no sustained evidence reporting a difference in mortality between the use DH,SLED, or CRRT in AKI patients, there is a tendency for earlier renal recovery and decreased progression to CKD with CRRT use [150,151]. The KDIGO guidelines recommend the use of CRRT and HD as complementary therapies, although CRRT should be favored in hemodynamically unstable patients and in patients with increased intracranial pressure [13]. Ultimately, the choice between RRT modalities relies on patient clinical status, resource availability, and local expertise [149].

RRT is essential to maintain volume, electrolyte, acid-base, and uremic solute homeostasis in AKI patients. It is also theorized that RRT can modulate inflammation, which might prove crucial in septic patients, though this remains uncertain $[147,152]$. Nonetheless, RRT requires central venous dialysis catheter insertion, the exposure of blood to an extracorporeal circuit, and anticoagulation, and it can be associated with hemodynamic instability, which may contribute to delayed kidney recovery [147,152].

The timing to start RRT remains controversial. According to the KDIGO guidelines, RRT should be started when life-threatening changes in fluid, electrolyte, and acid-base balances exist, and it is recommended to consider the broader clinical context and trends of laboratory values when making the decision to start RRT [13]. It is also non-consensual if RRT can change patient outcomes or is merely a surrogate for the critical illness on patient outcomes [153-156].

Recent randomized clinical trials have evaluated the optimal timing to start RRT in critically ill AKI patients. The heterogeneity in definitions of timing and criteria has contributed to lack of a strong recommendation $[153,154]$.

The Early Versus Late Initiation of RRT (ELAIN) was a single-center trial of 231 critically ill, mostly surgical AKI patients. In this study, Zarbock et al. defined the early group as starting RRT within $8 \mathrm{~h}$ of fulfilling KDIGO stage 2 AKI and elevated plasma NGAL levels, and they defined the delayed group as starting RRT within $12 \mathrm{~h}$ of developing KDIGO stage $3 \mathrm{AKI}$ or in the presence of an absolute indication [157]. The early RRT group was associated with $15 \%$ less mortality, greater RRT independence, and less hospitalization days than the delayed RRT group. However, the delayed group included $9 \%$ of patients who did not start RRT due to the recovery of kidney function [157].

In contrast, in the Artificial Kidney Initiation in Kidney Injury (AKIKI) multicenter trial of 620 critically ill AKI patients, an early RRT start did not decrease mortality, with no differences noted in hospital stays and renal recovery, and the delayed group had greater RRT-free days and fewer incidences of catheter-related infections [158]. In this study, early RRT was defined as starting RRT within $6 \mathrm{~h}$ of fulfilling KDIGO stage $3 \mathrm{AKI}$, and delayed RRT was defined as RRT start only in response to the development of absolute indications. Additionally, only $51 \%$ in the delayed group started RRT [158].

Considering the contrasting results of these studies, another multicenter trial was conducted in 488 patients with septic shock and severe AKI; this was entitled Initiation of Dialysis Early versus Late in the Intensive Care Unit (IDEAL-ICU) [159]. In this study, Barbar et al. defined the early group as RRT start within $12 \mathrm{~h}$ of achieving the failure stage of the RIFLE (Risk, Injury, Failure, Loss of kidney function, and End-stage kidney disease) classification without life-threatening AKI complications, and they defined the delayed group as starting RRT after a delay of $48 \mathrm{~h}$ of achieving the failure stage of the RIFLE classification. The results of the IDEAL-ICU trial were consistent with AKIKI and also demonstrated no significant difference in mortality between groups [159].

Only the ELAIN trial provided evidence that suggested the benefit of an early RRT start, which has not been verified in most recent studies. Several factors might have contributed to this conflicting evidence.

Firstly, the population studied, the AKI diagnostic criteria, and the definition of timing in each study were different. The ELAIN trial included a mixed ICU population but was mostly surgical patients, whereas the AKIKI and IDEAL trials included medical ICU patients with a higher proportion of sepsis. The ELAIN trial also included a significantly higher proportion of CKD patients (with a 
glomerular filtration rate of higher than $30 \mathrm{~mL} / \mathrm{min} / 1.73 \mathrm{~m}^{2}$ ) than the AKIKI and IDEAL trials ( $41 \%$ vs. $10 \%$ and $15 \%$, respectively). Patients enrolled in the AKIKI and IDEAL trials were at least stage 3 KDIGO or failure on the RIFLE classification, while this was only the case for patients in the delayed group in the ELAIN trial. Thus, the inclusion of less severe patients in the ELAIN trial might have beneficially influenced the outcome. Interestingly, patients in the ELAIN trial received delayed RRT at a significantly earlier point than the delayed group in the AKIKI and IDEAL trials ( 25.5 vs. 57 and $51.5 \mathrm{~h}$, respectively).

Secondly, RRT modalities were different in these trials. All patients in the ELAIN trial were started on continuous RRT, and a combination of continuous and intermittent RRT techniques were prescribed in the AKIKI and IDEAL trials. Therefore, the disparities between RRT modalities might have influenced the hemodynamic assessment, treatment, and outcome of these patients.

Finally, a lower proportion of patients in the delayed group of the AKIKI and IDEAL trials initiated RRT than the delayed group of the ELAIN trial ( $51 \%$ and $62 \%$ vs. $91 \%$, respectively). This suggests that a conservative approach to RRT start in response to persistent AKI or complications might be acceptable, as several patients with KDIGO stage 3 recovered renal function and ultimately did not require RRT.

The results of the ongoing Standard Versus Accelerated Initiation of Dialysis in Acute Kidney Injury (STARRT-AKI) and AKIKI 2 multicenter trials are highly anticipated in order to provide a more definitive answer to the problem of optimal timing for RRT start $[160,161]$.

The timing of initiation has only been assessed in critically ill and the post-surgical settings, $[162,163]$ and the inconsistent results have led to a perpetuation of the traditional recommendations of RRT start.

\section{Prevention of AKI}

In the absence of effective therapeutic interventions on established AKI and due to its significant on morbidity and mortality, we can only rely on AKI prevention and early diagnosis to reduce its incidence and detrimental consequences.

On the other hand, it could be argued that risk assessment is futile because it is unclear which interventions for high-risk patients should be implemented and whether these interventions are actually effective.

However, recent studies have suggested that the risk stratification of patients for AKI can allow for the employment of effective intervention and reduce the incidence of AKI, although there has been no evidence of benefit for long-term renal outcomes [164-166].

The recent Acute Disease Quality Initiative (ADQI) conference on "Quality Improvement for AKI" proposed that the range of care in AKI should be a continuum from risk assessment and prevention in the community setting, to AKI prevention in the hospital, to optimizing AKI management, and finally to the surveillance of AKD and the prevention of recurrent AKI and progression to CKD [167].

At least $50 \%$ of AKI episodes are believed to begin in the community setting, so health care professionals should identify at-risk patients (Table 2) and implement preventive interventions to decrease the incidence of AKI [168-170].

High-risk patients for AKI should have a kidney health assessment (KHA) every 12 months, at least 30 days before exposure and two-to-three days after exposure that carries AKI risk in order to define and modify their risk profile $[167,171]$. The KHA must include AKI and CKD history, blood pressure assessment, SCr level, urine dipstick, and medication list [167].

After an acute exposure to an AKI inciting event, namely nephrotoxic medications, radiocontrast, surgery, or acute disease, medications should be adjusted, further nephrotoxic exposures should be minimized, and AKI occurrence and its complications should be monitored [167].

At hospital admission, patients should also be screened for AKI risk [13,169,172]. In high-risk patients, the early correction of modifiable risk factors should be considered in order to prevent AKI occurrence $[64,167,173]$. 
The gold-standard of AKI prevention remains the optimization of hemodynamic and volume status, medication review such as the cessation of angiotensin-converting enzyme inhibitor/angiotensin receptor blocker (ACEi/ARB) and metformin, and the minimization of nephrotoxic exposure $[13,174]$.

\section{Follow-Up after AKI}

For patients with AKI, the main goal should be the recovery to baseline kidney function in the shortest period of time in order to reduce duration and disease severity, thus highlighting the role of early diagnosis and prompt management $[62,167,175]$.

To date, there remains no standardized AKI or AKD follow-up care, but several studies have reported low rates of nephrology follow-up after AKI across different settings. [176,177]. In the United States Renal Data System annual report of 2015, only 19\% of patients had a nephrology follow-up at 12 months after an AKI hospitalization [178]. In another study, only $4 \%$ of patients were referred to a nephrologist at three months and only $9 \%$ at one year, though the mortality rate during this period was $22 \%$ [179].

The benefit of nephrology referral is uncertain, however, recent studies have suggested that in high-risk patients, an early nephrology referral may improve survival. Indeed, Harel et al. reported that only $41 \%$ of AKI patients had a nephrology follow-up and that this was associated with a $24 \%$ mortality reduction in two years of follow-up [180].

Determining which patients are at higher risk for CKD development after AKI is crucial. Risk factors for CKD after AKI include the severity, duration, and recurrence of AKI; the timing of renal recovery; advanced age; lower baseline renal function; diabetes mellitus; hypertension; chronic heart failure; hypoalbuminemia; proteinuria; chronic liver disease; and a higher Charlson comorbidity index [181].

The KDIGO guidelines and the ADQI consensus recommend that after an episode of AKI, patients should be followed by a nephrologist at least three months after the episode in order to assess kidney recovery and/or progression to CKD or progressive CKD [13,167]. The follow-up evaluation should include kidney function and proteinuria to assess prognosis and outcome, medication reconciliation, patient education to nephrotoxic avoidance, and the employment of strategies to prevent CKD progression [167].

Further research is warranted to identify high-risk patients, define timing for nephrology follow-up, and to develop strategies to improve patient outcomes.

\section{Conclusions}

Currently, there are no established pharmacotherapies for AKI. Treatment strategies for AKI comprise hemodynamic stabilization, the eviction of nephrotoxins, and the treatment of AKI complications. The gold-standard of AKI prevention includes identifying at-risk patients, optimizing hemodynamic and volume statuses, reviewing medication, and minimizing nephrotoxic exposure. Considering the significant prognostic impact of AKI, it is crucial to focus further research on AKI prevention and therapy.

Author Contributions: The authors participated as follows: J.G. drafted the article, J.A.F. participated in the literature review of data, C.O. revised the article, and J.A.L. revised the article and approved the final version to be submitted for publication. All authors have read and agreed to the published version of the manuscript.

Funding: There was no funding for this study.

Conflicts of Interest: The authors declare no conflict of interest.

\section{References}

1. Susantitaphong, P.; Cruz, D.N.; Cerda, J.; Abulfaraj, M.; Alqahtani, F.; Koulouridis, I.; Jaber, B.L. Acute Kidney Injury Advisory Group of the American Society of Nephrology. World Incidence of AKI: A Meta-Analysis. Clin. J. Am. Soc. Nephrol. 2013, 8, 1482-1493. [CrossRef] 
2. Lameire, N.; Van Biesen, W.; Vanholder, R. The changing epidemiology of acute renal failure. Nat. Clin. Pract. Nephrol. 2006, 2, 364-377. [CrossRef]

3. Rodrigues, F.B.; Bruetto, R.G.; Torres, U.S.; Otaviano, A.P.; Zanetta, D.M.T.; Burdmann, E.A. Incidence and Mortality of Acute Kidney Injury after Myocardial Infarction: A Comparison between KDIGO and RIFLE Criteria. PLoS ONE 2013, 8, e69998. [CrossRef] [PubMed]

4. Luo, X.; Jiang, L.; Du, B.; Wen, Y.; Wang, M.; Xi, X. A comparison of different diagnostic criteria of acute kidney injury in critically ill patients. Crit. Care 2014, 18, R144. [CrossRef] [PubMed]

5. Fujii, T.; Uchino, S.; Takinami, M.; Bellomo, R. Validation of the Kidney Disease Improving Global Outcomes Criteria for AKI and Comparison of Three Criteria in Hospitalized Patients. Clin. J. Am. Soc. Nephrol. 2014, 9, 848-854. [CrossRef]

6. Bagshaw, S.M.; George, C.; Bellomo, R. Changes in the incidence and outcome for early acute kidney injury in a cohort of Australian intensive care units. Crit. Care 2007, 11, R68. [CrossRef] [PubMed]

7. Hoste, E.A.J.; Kellum, J.A.; Selby, N.M.; Zarbock, A.; Palevsky, P.M.; Bagshaw, S.M.; Goldstein, S.L.; Cerdá, J.; Chawla, L.S. Global epidemiology and outcomes of acute kidney injury. Nat. Rev. Nephrol. 2018, 14, $607-625$. [CrossRef] [PubMed]

8. Chertow, G.M.; Burdick, E.; Honour, M.; Bonventre, J.V.; Bates, D.W. Acute Kidney Injury, Mortality, Length of Stay, and Costs in Hospitalized Patients. J. Am. Soc. Nephrol. 2005, 16, 3365-3370. [CrossRef]

9. Hsu, R.K.; McCulloch, C.E.; Dudley, R.A.; Lo, L.J.; Hsu, C. Temporal Changes in Incidence of Dialysis-Requiring AKI. J. Am. Soc. Nephrol. 2012, 24, 37-42. [CrossRef]

10. Bellomo, R. The epidemiology of acute renal failure: 1975 versus 2005. Curr. Opin. Crit. Care 2006, 12, 557-560. [CrossRef]

11. Cruz, D.N.; Ronco, C. Acute kidney injury in the intensive care unit: Current trends in incidence and outcome. Crit. Care 2007, 11, 149. [CrossRef] [PubMed]

12. Bagshaw, S.M.; George, C.; Bellomo, R. Early acute kidney injury and sepsis: A multicentre evaluation. Crit. Care 2008, 12, R47. [CrossRef] [PubMed]

13. Khwaja, A. KDIGO Clinical Practice Guidelines for Acute Kidney Injury. Nephron 2012, 120, c179-c184. [CrossRef] [PubMed]

14. Gameiro, J.; Agapito Fonseca, J.; Jorge, S.; Lopes, J.A. Acute Kidney Injury Definition and Diagnosis: A Narrative Review. J. Clin. Med. 2018, 7, 307. [CrossRef] [PubMed]

15. Chawla, L.S.; Bellomo, R.; Bihorac, A.; Goldstein, S.L.; Siew, E.D.; Bagshaw, S.M.; Bittleman, D.; Cruz, D.; Endre, Z.; Fitzgerald, R.L.; et al. Acute kidney disease and renal recovery: Consensus report of the Acute Disease Quality Initiative (ADQI) 16 Workgroup. Nat. Rev. Nephrol. 2017, 13, 241-257. [CrossRef]

16. Moledina, D.G.; Parikh, C.R. Phenotyping of Acute Kidney Injury: Beyond Serum Creatinine. Semin. Nephrol. 2018, 38, 3-11. [CrossRef]

17. Waikar, S.S.; Betensky, R.A.; Emerson, S.C.; Bonventre, J.V. Imperfect Gold Standards for Kidney Injury Biomarker Evaluation. J. Am. Soc. Nephrol. 2011, 23, 13-21. [CrossRef]

18. Thomas, M.E.; Blaine, C.; Dawnay, A.; Devonald, M.A.; Ftouh, S.; Laing, C.; Latchem, S.; Lewington, A.; Milford, D.V.; Ostermann, M. The definition of acute kidney injury and its use in practice. Kidney Int. 2015, 87, 62-73. [CrossRef]

19. Macedo, E.; Malhotra, R.; Claure-Del Granado, R.; Fedullo, P.; Mehta, R.L. Defining urine output criterion for acute kidney injury in critically ill patients. Nephrol. Dial. Transplant. 2010, 26, 509-515. [CrossRef]

20. Schinstock, C.A.; Semret, M.H.; Wagner, S.J.; Borland, T.M.; Bryant, S.C.; Kashani, K.B.; Larson, T.S.; Lieske, J.C. Urinalysis is more specific and urinary neutrophil gelatinase-associated lipocalin is more sensitive for early detection of acute kidney injury. Nephrol. Dial. Transplant. 2012, 28, 1175-1185. [CrossRef]

21. Parikh, C.R.; Mishra, J.; Thiessen-Philbrook, H.; Dursun, B.; Ma, Q.; Kelly, C.; Dent, C.; Devarajan, P.; Edelstein, C.L. Urinary IL-18 is an early predictive biomarker of acute kidney injury after cardiac surgery. Kidney Int. 2006, 70, 199-203. [CrossRef] [PubMed]

22. Di Somma, S.; Magrini, L.; De Berardinis, B.; Marino, R.; Ferri, E.; Moscatelli, P.; Ballarino, P.; Carpinteri, G.; Noto, P.; Gliozzo, B.; et al. Additive value of blood neutrophil gelatinase-associated lipocalin to clinical judgement in acute kidney injury diagnosis and mortality prediction in patients hospitalized from the emergency department. Crit. Care 2013, 17, R29. [CrossRef] 
23. Bennett, M.; Dent, C.L.; Ma, Q.; Dastrala, S.; Grenier, F.; Workman, R.; Syed, H.; Ali, S.; Barasch, J.; Devarajan, P. Urine NGAL Predicts Severity of Acute Kidney Injury After Cardiac Surgery: A Prospective Study. Clin. J. Am. Soc. Nephrol. 2008, 3, 665-673. [CrossRef] [PubMed]

24. Hall, I.E.; Yarlagadda, S.G.; Coca, S.G.; Wang, Z.; Doshi, M.; Devarajan, P.; Han, W.K.; Marcus, R.J.; Parikh, C.R. IL-18 and Urinary NGAL Predict Dialysis and Graft Recovery after Kidney Transplantation. J. Am. Soc. Nephrol. 2009, 21, 189-197. [CrossRef] [PubMed]

25. Jia, H.-M.; Huang, L.-F.; Zheng, Y.; Li, W.-X. Diagnostic value of urinary tissue inhibitor of metalloproteinase-2 and insulin-like growth factor binding protein 7 for acute kidney injury: A meta-analysis. Crit. Care 2017, 21. [CrossRef]

26. Bargnoux, A.-S.; Piéroni, L.; Cristol, J.-P. Analytical study of a new turbidimetric assay for urinary neutrophil gelatinase-associated lipocalin (NGAL) determination. Clin. Chem. Lab. Med. 2013, 51. [CrossRef]

27. Westhoff, J.H.; Tönshoff, B.; Waldherr, S.; Pöschl, J.; Teufel, U.; Westhoff, T.H.; Fichtner, A. Urinary Tissue Inhibitor of Metalloproteinase-2 (TIMP-2) • Insulin-Like Growth Factor-Binding Protein 7 (IGFBP7) Predicts Adverse Outcome in Pediatric Acute Kidney Injury. PLoS ONE 2015, 10, e0143628. [CrossRef]

28. Lima, C.; Macedo, E. Urinary Biochemistry in the Diagnosis of Acute Kidney Injury. Dis. Markers 2018, 2018, 4907024. [CrossRef]

29. Han, W.K.; Bailly, V.; Abichandani, R.; Thadhani, R.; Bonventre, J.V. Kidney Injury Molecule-1 (KIM-1): A novel biomarker for human renal proximal tubule injury. Kidney Int. 2002, 62, 237-244. [CrossRef]

30. Ostermann, M.; Philips, B.J.; Forni, L.G. Clinical review: Biomarkers of acute kidney injury: Where are we now? Crit. Care 2012, 16, 233. [CrossRef]

31. Kashani, K.; Cheungpasitporn, W.; Ronco, C. Biomarkers of acute kidney injury: The pathway from discovery to clinical adoption. Clin. Chem. Lab. Med. 2017, 55, 1074-1089. [CrossRef] [PubMed]

32. Klein, S.J.; Brandtner, A.K.; Lehner, G.F.; Ulmer, H.; Bagshaw, S.M.; Wiedermann, C.J.; Joannidis, M. Biomarkers for prediction of renal replacement therapy in acute kidney injury: A systematic review and meta-analysis. Intensive Care Med. 2018, 44, 323-336. [CrossRef] [PubMed]

33. Vanmassenhove, J.; Vanholder, R.; Nagler, E.; Van Biesen, W. Urinary and serum biomarkers for the diagnosis of acute kidney injury: An in-depth review of the literature*. Nephrol. Dial. Transplant. 2012, 28, 254-273. [CrossRef]

34. Alge, J.L.; Arthur, J.M. Biomarkers of AKI: A Review of Mechanistic Relevance and Potential Therapeutic Implications. Clin. J. Am. Soc. Nephrol. 2014, 10, 147-155. [CrossRef]

35. Thongprayoon, C.; Hansrivijit, P.; Kovvuru, K.; Kanduri, S.R.; Torres-Ortiz, A.; Acharya, P.; Gonzalez-Suarez, M.L.; Kaewput, W.; Bathini, T.; Cheungpasitporn, W. Diagnostics, Risk Factors, Treatment and Outcomes of Acute Kidney Injury in a New Paradigm. J. Clin. Med. 2020, 9, 1104. [CrossRef]

36. Ali, T.; Khan, I.; Simpson, W.; Prescott, G.; Townend, J.; Smith, W.; Macleod, A. Incidence and Outcomes in Acute Kidney Injury: A Comprehensive Population-Based Study. J. Am. Soc. Nephrol. 2007, 18, 1292-1298. [CrossRef]

37. Lameire, N.H.; Bagga, A.; Cruz, D.; De Maeseneer, J.; Endre, Z.; Kellum, J.A.; Liu, K.D.; Mehta, R.L.; Pannu, N.; Van Biesen, W.; et al. Acute kidney injury: An increasing global concern. Lancet 2013, 382, 170-179. [CrossRef]

38. Grams, M.E.; Sang, Y.; Ballew, S.H.; Gansevoort, R.T.; Kimm, H.; Kovesdy, C.P.; Naimark, D.; Oien, C.; Smith, D.H.; Coresh, J.; et al. A Meta-analysis of the Association of Estimated GFR, Albuminuria, Age, Race, and Sex With Acute Kidney Injury. Am. J. Kidney Dis. 2015, 66, 591-601. [CrossRef]

39. De Zan, F.; Amigoni, A.; Pozzato, R.; Pettenazzo, A.; Murer, L.; Vidal, E. Acute Kidney Injury in Critically Ill Children: A Retrospective Analysis of Risk Factors. Blood Purif. 2020, 49, 1-7. [CrossRef]

40. Nie, S.; Tang, L.; Zhang, W.; Feng, Z.; Chen, X. Are There Modifiable Risk Factors to Improve AKI? BioMed Res. Int. 2017, 2017, 5605634. [CrossRef]

41. Anderson, S.; Eldadah, B.; Halter, J.B.; Hazzard, W.R.; Himmelfarb, J.; Horne, F.M.; Kimmel, P.L.; Molitoris, B.A.; Murthy, M.; O’Hare, A.M.; et al. Acute Kidney Injury in Older Adults. J. Am. Soc. Nephrol. 2011, 22, 28-38. [CrossRef]

42. Chawla, L.S.; Eggers, P.W.; Star, R.A.; Kimmel, P.L. Acute Kidney Injury and Chronic Kidney Disease as Interconnected Syndromes. N. Engl. J. Med. 2014, 371, 58-66. [CrossRef] 
43. Yang, L. How Acute Kidney Injury Contributes to Renal Fibrosis. In Renal Fibrosis: Mechanisms and Therapies; Springer: Singapore, 2019; pp. 117-142. [CrossRef]

44. Zhou, Q.; Zhao, C.; Xie, D.; Xu, D.; Bin, J.; Chen, P.; Liang, M.; Zhang, X.; Hou, F. Acute and acute-on-chronic kidney injury of patients with decompensated heart failure: Impact on outcomes. BMC Nephrol. 2012, $13,51$. [CrossRef]

45. Nie, S.; Feng, Z.; Xia, L.; Bai, J.; Xiao, F.; Liu, J.; Tang, L.; Chen, X. Risk factors of prognosis after acute kidney injury in hospitalized patients. Front. Med. 2017, 11, 393-402. [CrossRef]

46. Kane-Gill, S.L.; Sileanu, F.E.; Murugan, R.; Trietley, G.S.; Handler, S.M.; Kellum, J.A. Risk Factors for Acute Kidney Injury in Older Adults With Critical Illness: A Retrospective Cohort Study. Am. J. Kidney Dis. 2015, 65, 860-869. [CrossRef]

47. Gameiro, J.; Agapito Fonseca, J.; Jorge, S.; Lopes, J.A. Acute kidney injury in HIV-infected patients: A critical review. HIV Med. 2019, 20. [CrossRef]

48. Wyatt, C.M.; Arons, R.R.; Klotman, P.E.; Klotman, M.E. Acute renal failure in hospitalized patients with HIV: Risk factors and impact on in-hospital mortality. AIDS 2006, 20, 561-565. [CrossRef]

49. Hoste, E.A.; Bagshaw, S.M.; Bellomo, R.; Cely, C.M.; Colman, R.; Cruz, D.N.; Edipidis, K.; Forni, L.G.; Gomersall, C.D.; Govil, D.; et al. Epidemiology of acute kidney injury in critically ill patients: The multinational AKI-EPI study. Intensive Care Med. 2015, 41, 1411-1423. [CrossRef]

50. Ejaz, A.A.; Beaver, T.M.; Shimada, M.; Sood, P.; Lingegowda, V.; Schold, J.D.; Kim, T.; Johnson, R.J. Uric Acid: A Novel Risk Factor for Acute Kidney Injury in High-Risk Cardiac Surgery Patients? Am. J. Nephrol. 2009, 30, 425-429. [CrossRef]

51. Ejaz, A.A.; Kambhampati, G.; Ejaz, N.I.; Dass, B.; Lapsia, V.; Arif, A.A.; Asmar, A.; Shimada, M.; Alsabbagh, M.M.; Aiyer, R.; et al. Post-operative serum uric acid and acute kidney injury. J. Nephrol. 2012, 25, 497-505. [CrossRef]

52. Lapsia, V.; Johnson, R.J.; Dass, B.; Shimada, M.; Kambhampati, G.; Ejaz, N.I.; Arif, A.A.; Ejaz, A.A. Elevated Uric Acid Increases the Risk for Acute Kidney Injury. Am. J. Med. 2012, 125, 302.e9-302.e17. [CrossRef]

53. Guo, W.; Liu, Y.; Chen, J.-Y.; Chen, S.Q.; Li, H.L.; Duan, C.Y.; Liu, H.Y.; Tan, N. Hyperuricemia Is an Independent Predictor of Contrast-Induced Acute Kidney Injury and Mortality in Patients Undergoing Percutaneous Coronary Intervention. Angiology 2015, 66, 721-726. [CrossRef]

54. Kellum, J.A.; Lameire, N. Diagnosis, evaluation, and management of acute kidney injury: A KDIGO summary (Part 1). Crit. Care 2013, 17, 204. [CrossRef]

55. Ostermann, M.; Liu, K. Pathophysiology of AKI. Best Pract. Res. Clin. Anaesthesiol. 2017, 31, $305-314$. [CrossRef]

56. Case, J.; Khan, S.; Khalid, R.; Khan, A. Epidemiology of Acute Kidney Injury in the Intensive Care Unit. Crit. Care Res. Pract. 2013, 2013, 479730. [CrossRef]

57. Uchino, S.; Kellum, J.A.; Bellomo, R.; Doig, G.S.; Morimatsu, H.; Morgera, S.; Schetz, M.; Tan, I.; Bouman, C.; Macedo, E.; et al. Acute Renal Failure in Critically Ill Patients: A Multinational, Multicenter Study. JAMA 2005, 294, 813. [CrossRef]

58. Akcay, A.; Nguyen, Q.; Edelstein, C.L. Mediators of Inflammation in Acute Kidney Injury. Mediat. Inflamm. 2009, 2019, 137072. [CrossRef]

59. Basile, D.P.; Anderson, M.D.; Sutton, T.A. Pathophysiology of Acute Kidney Injury. In Comprehensive Physiology; John Wiley \& Sons, Inc.: Hoboken, NJ, USA, 2012. [CrossRef]

60. Devarajan, P. Update on Mechanisms of Ischemic Acute Kidney Injury. J. Am. Soc. Nephrol. 2006, 17, 1503-1520. [CrossRef]

61. Harty, J. Prevention and management of acute kidney injury. Ulster Med. J. 2014, 83, 149-157.

62. Moore, P.K.; Hsu, R.K.; Liu, K.D. Management of Acute Kidney Injury: Core Curriculum 2018. Am. J. Kidney Dis. 2018, 72, 136-148. [CrossRef]

63. Ostermann, M.; Liu, K.; Kashani, K. Fluid Management in Acute Kidney Injury. Chest 2019, 156, 594-603. [CrossRef]

64. Meersch, M.; Schmidt, C.; Hoffmeier, A.; Van Aken, H.; Wempe, C.; Gerss, J.; Zarbock, A. Prevention of cardiac surgery-associated AKI by implementing the KDIGO guidelines in high risk patients identified by biomarkers: The PrevAKI randomized controlled trial. Intensive Care Med. 2017, 43, 1551-1561. [CrossRef]

65. Bagshaw, S.M.; Lapinsky, S.; Dial, S.; Arabi, Y.; Dodek, P.; Wood, G.; Ellis, P.; Guzman, J.; Marshall, J.; Parrillo, J.E.; et al. Acute kidney injury in septic shock: Clinical outcomes and impact of duration of hypotension prior to initiation of antimicrobial therapy. Intensive Care Med. 2009, 35, 871-881. [CrossRef] 
66. Bouchard, J.; Soroko, S.B.; Chertow, G.M.; Himmelfarb, J.; Ikizler, T.A.; Paganini, E.P.; Mehta, R.L. Program to Improve Care in Acute Renal Disease (PICARD) Study Group. Fluid accumulation, survival and recovery of kidney function in critically ill patients with acute kidney injury. Kidney Int. 2009, 76, 422-427. [CrossRef]

67. Wang, N.; Jiang, L.; Zhu, B.; Wen, Y.; Xi, X.-M. Fluid balance and mortality in critically ill patients with acute kidney injury: A multicenter prospective epidemiological study. Crit. Care 2015, 19, 371. [CrossRef]

68. Vaara, S.T.; Korhonen, A.M.; Kaukonen, K.M.; Nisula, S.; Inkinen, O.; Hoppu, S.; Laurila, J.J.; Mildh, L.; Reinikainen, M.; Lund, V.; et al. Fluid overload is associated with an increased risk for 90-day mortality in critically ill patients with renal replacement therapy: Data from the prospective FINNAKI study. Crit. Care 2012, 16, R197. [CrossRef]

69. Bednarczyk, J.M.; Fridfinnson, J.A.; Kumar, A.; Blanchard, L.; Rabbani, R.; Bell, D.; Funk, D.; Turgeon, A.F.; Abou-Setta, A.M.; Zarychanski, R. Incorporating Dynamic Assessment of Fluid Responsiveness Into Goal-Directed Therapy. Crit. Care Med. 2017, 45, 1538-1545. [CrossRef]

70. Saugel, B.; Vincent, J.-L.; Wagner, J.Y. Personalized hemodynamic management. Curr. Opin. Crit. Care 2017, 23, 334-341. [CrossRef]

71. Varrier, M.; Ostermann, M. Fluid Composition and Clinical Effects. Crit. Care Clin. 2015, 31, 823-837. [CrossRef]

72. Finfer, S.; Bellomo, R.; Boyce, N.; French, J.; Myburgh, J.; Norton, R. A Comparison of Albumin and Saline for Fluid Resuscitation in the Intensive Care Unit. N. Engl. J. Med. 2004, 350, 2247-2256. [CrossRef]

73. Caironi, P.; Tognoni, G.; Masson, S.; Fumagalli, R.; Pesenti, A.; Romero, M.; Fanizza, C.; Caspani, L.; Faenza, S.; Grasselli, G.; et al. Albumin Replacement in Patients with Severe Sepsis or Septic Shock. N. Engl. J. Med. 2014, 370, 1412-1421. [CrossRef]

74. The SAFE Study Investigators. Saline or Albumin for Fluid Resuscitation in Patients with Traumatic Brain Injury. N. Engl. J. Med. 2007, 357, 874-884. [CrossRef]

75. Annane, D. Effects of Fluid Resuscitation With Colloids vs Crystalloids on Mortality in Critically Ill Patients Presenting With Hypovolemic Shock. JAMA 2013, 310, 1809. [CrossRef]

76. Rhodes, A.; Evans, L.E.; Alhazzani, W.; Levy, M.M.; Antonelli, M.; Ferrer, R.; Kumar, A.; Sevransky, J.E.; Sprung, C.L.; Nunnally, M.E.; et al. Surviving Sepsis Campaign: International Guidelines for Management of Sepsis and Septic Shock: 2016. Intensive Care Med. 2017, 43, 304-377. [CrossRef]

77. Bayer, O.; Reinhart, K.; Kohl, M.; Kabisch, B.; Marshall, J.; Sakr, Y.; Bauer, M.; Hartog, C.; Schwarzkopf, D.; Riedemann, N. Effects of fluid resuscitation with synthetic colloids or crystalloids alone on shock reversal, fluid balance, and patient outcomes in patients with severe sepsis. Crit. Care Med. 2012, 40, 2543-2551. [CrossRef]

78. Boyer, T.D.; Sanyal, A.J.; Wong, F.; Frederick, R.T.; Lake, J.R.; O’Leary, J.G.; Ganger, D.; Jamil, K.; Pappas, S.C.; REVERSE Study Investigators. Terlipressin Plus Albumin Is More Effective Than Albumin Alone in Improving Renal Function in Patients With Cirrhosis and Hepatorenal Syndrome Type 1. Gastroenterology 2016, 150, 1579-1589.e2. [CrossRef]

79. Lee, E.H.; Kim, W.J.; Kim, J.Y.; Chin, J.H.; Choi, D.K.; Sim, J.Y.; Choo, S.J.; Chung, C.H.; Lee, J.W.; Choi, I.C. Effect of Exogenous Albumin on the Incidence of Postoperative Acute Kidney Injury in Patients Undergoing Off-pump Coronary Artery Bypass Surgery with a Preoperative Albumin Level of Less Than 4.0 g/dl. Anesthesiology 2016, 124, 1001-1011. [CrossRef]

80. Udeh, C.I.; You, J.; Wanek, M.R.; Dalton, J.; Udeh, B.L.; Demirjian, S.; Rahman, N.; Hata, J.S. Acute kidney injury in postoperative shock: Is hyperoncotic albumin administration an unrecognized resuscitation risk factor? Perioper Med. 2018, 7, 29. [CrossRef]

81. Schortgen, F.; Girou, E.; Deye, N.; Brochard, L. The risk associated with hyperoncotic colloids in patients with shock. Intensive Care Med. 2008, 34, 2157-2168. [CrossRef]

82. Myburgh, J.A.; Finfer, S.; Bellomo, R.; Billot, L.; Cass, A.; Gattas, D.; Glass, P.; Lipman, J.; Liu, B.; McArthur, C.; et al. Hydroxyethyl Starch or Saline for Fluid Resuscitation in Intensive Care. N. Engl. J. Med. 2012, 367, 1901-1911. [CrossRef]

83. Perner, A.; Haase, N.; Guttormsen, A.B.; Tenhunen, J.; Klemenzson, G.; Åneman, A.; Madsen, K.R.; Møller, M.H.; Elkjær, J.M.; Poulsen, L.M.; et al. Hydroxyethyl Starch 130/0.42 versus Ringer's Acetate in Severe Sepsis. N. Engl. J. Med. 2012, 367, 124-134. [CrossRef] 
84. Moeller, C.; Fleischmann, C.; Thomas-Rueddel, D.; Vlasakov, V.; Rochwerg, B.; Theurer, P.; Gattinoni, L.; Reinhart, K.; Hartog, C.S. How safe is gelatin? A systematic review and meta-analysis of gelatin-containing plasma expanders vs crystalloids and albumin. J. Crit. Care 2016, 35, 75-83. [CrossRef]

85. Semler, M.W.; Self, W.H.; Wanderer, J.P.; Ehrenfeld, J.M.; Wang, L.; Byrne, D.W.; Stollings, J.L.; Kumar, A.B.; Hughes, C.G.; Hernandez, A.; et al. Balanced Crystalloids versus Saline in Critically Ill Adults. N. Engl. J. Med. 2018, 378, 829-839. [CrossRef]

86. McCluskey, S.A.; Karkouti, K.; Wijeysundera, D.; Minkovich, L.; Tait, G.; Beattie, W.S. Hyperchloremia After Noncardiac Surgery Is Independently Associated with Increased Morbidity and Mortality. Anesth Analg. 2013, 117, 412-421. [CrossRef]

87. Chowdhury, A.H.; Cox, E.F.; Francis, S.T.; Lobo, D.N. A Randomized, Controlled, Double-Blind Crossover Study on the Effects of 2-L Infusions of $0.9 \%$ Saline and Plasma-Lyte ${ }^{\circledR} 148$ on Renal Blood Flow Velocity and Renal Cortical Tissue Perfusion in Healthy Volunteers. Ann. Surg. 2012, 256, 18-24. [CrossRef]

88. Yunos, N.M.; Bellomo, R.; Hegarty, C.; Story, D.; Ho, L.; Bailey, M. Association Between a Chloride-Liberal vs Chloride-Restrictive Intravenous Fluid Administration Strategy and Kidney Injury in Critically Ill Adults. JAMA 2012, 308, 1566. [CrossRef]

89. Raghunathan, K.; Shaw, A.; Nathanson, B.; Stürmer, T.; Brookhart, A.; Stefan, M.S.; Setoguchi, S.; Beadles, C.; Lindenauer, P.K. Association Between the Choice of IV Crystalloid and In-Hospital Mortality Among Critically Ill Adults With Sepsis*. Crit. Care Med. 2014, 42, 1585-1591. [CrossRef]

90. Reddy, S.K.; Bailey, M.J.; Beasley, R.W.; Bellomo, R.; Mackle, D.M.; Psirides, A.J.; Young, P.J. Effect of 0.9\% Saline or Plasma-Lyte 148 as Crystalloid Fluid Therapy in the Intensive Care Unit on Blood Product Use and Postoperative Bleeding After Cardiac Surgery. J. Cardiothorac. Vasc. Anesth. 2017, 31, 1630-1638. [CrossRef]

91. Young, P.; Bailey, M.; Beasley, R.; Henderson, S.; Mackle, D.; McArthur, C.; McGuinness, S.; Mehrtens, J.; Myburgh, J.; Psirides, A.; et al. Effect of a Buffered Crystalloid Solution vs Saline on Acute Kidney Injury Among Patients in the Intensive Care Unit. JAMA 2015, 314, 1701. [CrossRef]

92. Self, W.H.; Semler, M.W.; Wanderer, J.P.; Wang, L.; Byrne, D.W.; Collins, S.P.; Slovis, C.M.; Lindsell, C.J.; Ehrenfeld, J.M.; Siew, E.D.; et al. Balanced Crystalloids versus Saline in Noncritically Ill Adults. N. Engl. J. Med. 2018, 378, 819-828. [CrossRef]

93. Sen, A.; Keener, C.M.; Sileanu, F.E.; Foldes, E.; Clermont, G.; Murugan, R.; Kellum, J.A. Chloride Content of Fluids Used for Large-Volume Resuscitation Is Associated With Reduced Survival. Crit. Care Med. 2017, 45, e146-e153. [CrossRef] [PubMed]

94. Asfar, P.; Meziani, F.; Hamel, J.F.; Grelon, F.; Megarbane, B.; Anguel, N.; Mira, J.P.; Dequin, P.F.; Gergaud, S.; Weiss, N.; et al. High versus Low Blood-Pressure Target in Patients with Septic Shock. N. Engl. J. Med. 2014, 370, 1583-1593. [CrossRef] [PubMed]

95. Kato, R.; Pinsky, M.R. Personalizing blood pressure management in septic shock. Ann. Intensive Care 2015, 5, 41. [CrossRef] [PubMed]

96. Futier, E.; Lefrant, J.Y.; Guinot, P.G.; Godet, T.; Lorne, E.; Cuvillon, P.; Bertran, S.; Leone, M.; Pastene, B.; Piriou, V.; et al. Effect of Individualized vs Standard Blood Pressure Management Strategies on Postoperative Organ Dysfunction Among High-Risk Patients Undergoing Major Surgery. JAMA 2017, 318, 1346. [CrossRef]

97. De Backer, D.; Biston, P.; Devriendt, J.; Madl, C.; Chochrad, D.; Aldecoa, C.; Brasseur, A.; Defrance, P.; Gottignies, P.; Vincent, J.L.; et al. Comparison of Dopamine and Norepinephrine in the Treatment of Shock. N. Engl. J. Med. 2010, 362, 779-789. [CrossRef]

98. Hernández, G.; Teboul, J.-L.; Bakker, J. Norepinephrine in septic shock. Intensive Care Med. 2019, 45, 687-689. [CrossRef]

99. Leone, M.; Albanèse, J.; Delmas, A.; Chaabane, W.; Garnier, F.; Martin, C. TERLIPRESSIN IN CATECHOLAMINE-RESISTANT SEPTIC SHOCK PATIENTS. Shock 2004, 22, 314-319. [CrossRef]

100. Albanèse, J.; Leone, M.; Delmas, A.; Martin, C. Terlipressin or norepinephrine in hyperdynamic septic shock: A prospective, randomized study*. Crit. Care Med. 2005, 33, 1897-1902. [CrossRef]

101. Gordon, A.C.; Mason, A.J.; Thirunavukkarasu, N.; Perkins, G.D.; Cecconi, M.; Cepkova, M.; Pogson, D.G.; Aya, H.D.; Anjum, A.; Frazier, G.J.; et al. Effect of Early Vasopressin vs Norepinephrine on Kidney Failure in Patients With Septic Shock. JAMA 2016, 316, 509. [CrossRef] 
102. Russell, J.A.; Walley, K.R.; Singer, J.; Gordon, A.C.; Hébert, P.C.; Cooper, D.J.; Holmes, C.L.; Mehta, S.; Granton, J.T.; Storms, M.M.; et al. Vasopressin versus Norepinephrine Infusion in Patients with Septic Shock. N. Engl. J. Med. 2008, 358, 877-887. [CrossRef]

103. Tumlin, J.A.; Murugan, R.; Deane, A.M.; Ostermann, M.; Busse, L.W.; Ham, K.R.; Kashani, K.; Szerlip, H.M.; Prowle, J.R.; Bihorac, A.; et al. Outcomes in Patients with Vasodilatory Shock and Renal Replacement Therapy Treated with Intravenous Angiotensin II. Crit. Care Med. 2018, 46, 949-957. [CrossRef] [PubMed]

104. Denton, M.D.; Chertow, G.M.; Brady, H.R. "Renal-dose” dopamine for the treatment of acute renal failure: Scientific rationale, experimental studies and clinical trials. Kidney Int. 1996, 50, 4-14. [CrossRef] [PubMed]

105. Friedrich, J.O.; Adhikari, N.; Herridge, M.S.; Beyene, J. Meta-Analysis: Low-Dose Dopamine Increases Urine Output but Does Not Prevent Renal Dysfunction or Death. Ann. Intern Med. 2005, 142, 510. [CrossRef] [PubMed]

106. Lauschke, A.; Teichgräber, U.K.M.; Frei, U.; Eckardt, K.-U. 'Low-dose' dopamine worsens renal perfusion in patients with acute renal failure. Kidney Int. 2006, 69, 1669-1674. [CrossRef] [PubMed]

107. Schenarts, P.J.; Sagraves, S.G.; Bard, M.R.; Toschlog, E.; Coettler, C.; Newell, M.; Rotondo, M. Low-Dose Dopamine: A Physiologically Based Review. Curr. Surg. 2006, 63, 219-225. [CrossRef]

108. Mathur, V.S.; Swan, S.K.; Lambrecht, L.J.; Anjum, S.; Fellmann, J.; McGuire, D.; Epstein, M.; Luther, R.R. The effects of fenoldopam, a selective dopamine receptor agonist, on systemic and renal hemodynamics in normotensive subjects. Crit. Care Med. 1999, 27, 1832-1837. [CrossRef]

109. Landoni, G.; Biondi-Zoccai, G.G.L.; Tumlin, J.A.; Bov, T.; Luca, M.; Calabro, M.G.; Ranucci, M.; Zangrillo, A. Beneficial Impact of Fenoldopam in Critically Ill Patients with or at Risk for Acute Renal Failure: A Meta-Analysis of Randomized Clinical Trials. Am. J. Kidney Dis. 2007, 49, 56-68. [CrossRef]

110. Stone, G.W.; McCullough, P.A.; Tumlin, J.A.; Lepor, N.E.; Madyoon, H.; Murray, P.; Wang, A.; Chu, A.A.; Schaer, G.L.; Stevens, M.; et al. Fenoldopam Mesylate for the Prevention of Contrast-Induced Nephropathy. JAMA 2003, 290, 2284. [CrossRef]

111. Allaqaband, S.; Tumuluri, R.; Malik, A.M.; Gupta, A.; Volkert, P.; Shalev, Y.; Bajwa, T. Prospective randomized study of $\mathrm{N}$-acetylcysteine, fenoldopam, and saline for prevention of radiocontrast-induced nephropathy. Catheter. Cardiovasc. Interv. 2002, 57, 279-283. [CrossRef]

112. Nigwekar, S.U.; Waikar, S.S. Diuretics in Acute Kidney Injury. Semin. Nephrol. 2011, 31, 523-534. [CrossRef]

113. Ho, K.M. Meta-analysis of frusemide to prevent or treat acute renal failure. BMJ 2006, 333, 420. [CrossRef] [PubMed]

114. Ho, K.M.; Power, B.M. Benefits and risks of furosemide in acute kidney injury. Anaesthesia 2010, 65, $283-293$. [CrossRef]

115. Uchino, S.; Doig, G.; Bellomo, R.; Morimatsu, H.; Morgera, S.; Schetz, M.; Tan, I.; Bouman, C.; Macedo, E.; Gibney, N.; et al. Diuretics and mortality in acute renal failure*. Crit. Care Med. 2004, 32, 1669-1677. [CrossRef]

116. Mehta, R.L. Diuretics, Mortality, and Nonrecovery of Renal Function in Acute Renal Failure. JAMA 2002, 288, 2547. [CrossRef] [PubMed]

117. Perazella, M.A. Drug use and nephrotoxicity in the intensive care unit. Kidney Int. 2012, 81, 1172-1178. [CrossRef] [PubMed]

118. Morales-Alvarez, M.C. Nephrotoxicity of Antimicrobials and Antibiotics. Adv. Chronic. Kidney Dis. 2020, 27, 31-37. [CrossRef]

119. Pannu, N.; Nadim, M.K. An overview of drug-induced acute kidney injury. Crit. Care Med. 2008, 36, S216-S223. [CrossRef]

120. Perazella, M.A. Renal Vulnerability to Drug Toxicity. Clin. J. Am. Soc. Nephrol. 2009, 4, 1275-1283. [CrossRef]

121. Nolin, T.D.; Himmelfarb, J. Mechanisms of Drug-Induced Nephrotoxicity. In Adverse Drug Reactions; Springer: Berlin/Heidelberg, Germany, 2010; pp. 111-130. [CrossRef]

122. Perazella, M.A.; Markowitz, G.S. Drug-induced acute interstitial nephritis. Nat. Rev. Nephrol. 2010, 6, 461-470. [CrossRef]

123. Hausenloy, D.J.; Yellon, D.M. Remote ischaemic preconditioning: Underlying mechanisms and clinical application. Cardiovasc. Res. 2008, 79, 377-386. [CrossRef] 
124. Menting, T.P.; Wever, K.E.; Hendriks, E.J.; Van der Vliet, D.J.; Rovers, M.M.; Warle, M.C. Ischaemic preconditioning for the reduction of renal ischaemia reperfusion injury. In Cochrane Database of Systematic Reviews; Menting, T.P., Ed.; John Wiley \& Sons, Ltd.: Chichester, UK, 2013. [CrossRef]

125. Ghaemian, A.; Yazdani, J.; Azizi, S.; Farsavian, A.A.; Nabati, M.; Malekrah, A.; Dabirian, M.; Espahbodi, F.; Mirjani, B.; Mohsenipouya, H.; et al. Remote Ischemic Preconditioning To Reduce Contrast-Induced Nephropathy: A Randomized Controlled Trial. Eur. J. Vasc. Endovasc. Surg. 2015, 50, 527-532. [CrossRef]

126. Zarbock, A.; Schmidt, C.; Van Aken, H.; Wempe, C.; Martens, S.; Zahn, P.K.; Wolf, B.; Goebel, U.; Schwer, C.I.; Rosenberger, P.; et al. Effect of Remote Ischemic Preconditioning on Kidney Injury Among High-Risk Patients Undergoing Cardiac Surgery. JAMA 2015, 313, 2133. [CrossRef] [PubMed]

127. Huang, J.; Chen, Y.; Dong, B.; Kong, W.; Zhang, J.; Xue, W.; Liu, D.; Huang, Y. Effect of remote ischaemic preconditioning on renal protection in patients undergoing laparoscopic partial nephrectomy: A 'blinded' randomised controlled trial. BJU Int. 2013, 112, 74-80. [CrossRef] [PubMed]

128. Hu, J.; Liu, S.; Jia, P.; Xu, X.; Song, N.; Zhang, T.; Chen, R.; Ding, X. Protection of remote ischemic preconditioning against acute kidney injury: A systematic review and meta-analysis. Crit. Care 2016, $20,111$. [CrossRef] [PubMed]

129. Nieminen, M.S.; Pollesello, P.; Vajda, G.; Papp, Z. Effects of Levosimendan on the Energy Balance: Preclinical and Clinical Evidence. J. Cardiovasc. Pharmacol. 2009, 53, 302-310. [CrossRef]

130. Faisal, S.A.; Apatov, D.A.; Ramakrishna, H.; Weiner, M.M. Levosimendan in Cardiac Surgery: Evaluating the Evidence. J. Cardiothorac. Vasc. Anesth. 2019, 33, 1146-1158. [CrossRef]

131. Zhou, C.; Gong, J.; Chen, D.; Wang, W.; Liu, M.; Liu, B. Levosimendan for Prevention of Acute Kidney Injury after Cardiac Surgery: A Meta-analysis of Randomized Controlled Trials. Am. J. Kidney Dis. 2016, 67, 408-416. [CrossRef] [PubMed]

132. Ramachandran, G.; Tulapurkar, M.E.; Harris, K.M.; Arad, G.; Shirvan, A.; Shemesh, R.; Detolla, L.J.; Benazzi, C.; Opal, S.M.; Kaempfer, R.; et al. A Peptide Antagonist of CD28 Signaling Attenuates Toxic Shock and Necrotizing Soft-Tissue Infection Induced by Streptococcus pyogenes. J. Infect. Dis. 2013, 207, 1869-1877. [CrossRef] [PubMed]

133. Bulger, E.M.; Maier, R.V.; Sperry, J.; Joshi, M.; Henry, S.; Moore, F.A.; Moldawer, L.L.; Demetriades, D.; Talving, P.; Schreiber, M.; et al. A Novel Drug for Treatment of Necrotizing Soft-Tissue Infections. JAMA Surg. 2014, 149, 528. [CrossRef] [PubMed]

134. Holick, M.F. Vitamin D Deficiency. N. Engl. J. Med. 2007, 357, 266-281. [CrossRef] [PubMed]

135. Amrein, K.; Christopher, K.B.; McNally, J.D. Understanding vitamin D deficiency in intensive care patients. Intensive Care Med. 2015, 41, 1961-1964. [CrossRef] [PubMed]

136. De Haan, K.; Groeneveld, A.J.; de Geus, H.R.; Egal, M.; Struijs, A. Vitamin D deficiency as a risk factor for infection, sepsis and mortality in the critically ill: Systematic review and meta-analysis. Crit. Care 2014, $18,660$. [CrossRef]

137. Ala-Kokko, T.I.; Mutt, S.J.; Nisula, S.; Koskenkari, J.; Liisanantti, J.; Ohtonen, P.; Poukkanen, M.; Laurila, J.J.; Pettilä, V.; Herzig, K.H.; et al. Vitamin D deficiency at admission is not associated with 90-day mortality in patients with severe sepsis or septic shock: Observational FINNAKI cohort study. Ann. Med. 2016, 48, 67-75. [CrossRef]

138. Wolf, M.; Betancourt, J.; Chang, Y.; Shah, A.; Teng, M.; Tamez, H.; Gutierrez, O.; Camargo, C.A., Jr.; Melamed, M.; Norris, K.; et al. Impact of Activated Vitamin D and Race on Survival among Hemodialysis Patients. J. Am. Soc. Nephrol. 2008, 19, 1379-1388. [CrossRef]

139. Lai, L.; Qian, J.; Yang, Y.; Xie, Q.; You, H.; Zhou, Y.; Ma, S.; Hao, C.; Gu, Y.; Ding, F. Is the Serum Vitamin D Level at the Time of Hospital-Acquired Acute Kidney Injury Diagnosis Associated with Prognosis? PLoS ONE 2013, 8, e64964. [CrossRef] [PubMed]

140. Cameron, L.K.; Lei, K.; Smith, S.; Doyle, N.L.; Doyle, J.F.; Flynn, K.; Purchase, N.; Smith, J.; Chan, K.; Kamara, F.; et al. Vitamin D levels in critically ill patients with acute kidney injury: A protocol for a prospective cohort study (VID-AKI). BMJ Open 2017, 7, e016486. [CrossRef]

141. Peters, E.; Masereeuw, R.; Pickkers, P. The Potential of Alkaline Phosphatase as a Treatment for Sepsis-Associated Acute Kidney Injury. Nephron Clin. Pract. 2014, 127, 144-148. [CrossRef]

142. Peters, E.; Geraci, S.; Heemskerk, S.; Wilmer, M.J.; Bilos, A.; Kraenzlin, B.; Gretz, N.; Pickkers, P.; Masereeuw, R. Alkaline phosphatase protects against renal inflammation through dephosphorylation of lipopolysaccharide and adenosine triphosphate. Br. J. Pharmacol. 2015, 172, 4932-4945. [CrossRef] 
143. Peters, E.; Heemskerk, S.; Masereeuw, R.; Pickkers, P. Alkaline Phosphatase: A Possible Treatment for Sepsis-Associated Acute Kidney Injury in Critically Ill Patients. Am. J. Kidney Dis. 2014, 63, 1038-1048. [CrossRef]

144. Pickkers, P.; Heemskerk, S.; Schouten, J.; Laterre, P.F.; Vincent, J.L.; Beishuizen, A.; Jorens, P.G.; Spapen, H.; Bulitta, M.; Peters, W.H.; et al. Alkaline phosphatase for treatment of sepsis-induced acute kidney injury: A prospective randomized double-blind placebo-controlled trial. Crit. Care 2012, 16, R14. [CrossRef]

145. Molitoris, B.A.; Dagher, P.C.; Sandoval, R.M.; Campos, S.B.; Ashush, H.; Fridman, E.; Brafman, A.; Faerman, A.; Atkinson, S.J.; Thompson, J.D.; et al. siRNA Targeted to p53 Attenuates Ischemic and Cisplatin-Induced Acute Kidney Injury. J. Am. Soc. Nephrol. 2009, 20, 1754-1764. [CrossRef] [PubMed]

146. Demirjian, S.; Ailawadi, G.; Polinsky, M.; Bitran, D.; Silberman, S.; Shernan, S.K.; Burnier, M.; Hamilton, M.; Squiers, E.; Erlich, S.; et al. Safety and Tolerability Study of an Intravenously Administered Small Interfering Ribonucleic Acid (siRNA) Post On-Pump Cardiothoracic Surgery in Patients at Risk of Acute Kidney Injury. Kidney Int. Rep. 2017, 2, 836-843. [CrossRef] [PubMed]

147. Bagshaw, S.M.; Wald, R. Strategies for the optimal timing to start renal replacement therapy in critically ill patients with acute kidney injury. Kidney Int. 2017, 91, 1022-1032. [CrossRef] [PubMed]

148. Ostermann, M.; Joannidis, M.; Pani, A.; Floris, M.; De Rosa, S.; Kellum, J.A.; Ronco, C. 17th Acute Disease Quality Initiative (ADQI) Consensus Group. Patient Selection and Timing of Continuous Renal Replacement Therapy. Blood Purif. 2016, 42, 224-237. [CrossRef] [PubMed]

149. Wang, A.Y.; Bellomo, R. Renal replacement therapy in the ICU. Curr. Opin. Crit. Care 2018, 24, 437-442. [CrossRef] [PubMed]

150. Wald, R.; Shariff, S.Z.; Adhikari, N.K.; Bagshaw, S.M.; Burns, K.E.; Friedrich, J.O.; Garg, A.X.; Harel, Z.; Kitchlu, A.; Ray, J.G. The Association Between Renal Replacement Therapy Modality and Long-Term Outcomes Among Critically Ill Adults With Acute Kidney Injury. Crit. Care Med. 2014, 42, 868-877. [CrossRef] [PubMed]

151. Liang, K.V.; Sileanu, F.E.; Clermont, G.; Murugan, R.; Pike, F.; Palevsky, P.M.; Kellum, J.A. Modality of RRT and Recovery of Kidney Function after AKI in Patients Surviving to Hospital Discharge. Clin. J. Am. Soc. Nephrol. 2016, 11, 30-38. [CrossRef]

152. Bagshaw, S.M.; Wald, R. Indications and Timing of Continuous Renal Replacement Therapy Application. In 40 Years of Continuous Renal Replacement Therapy; Karger Publishers: Basel, Switzerland, 2018; pp. $25-37$. [CrossRef]

153. Clark, E.; Wald, R.; Levin, A.; Bouchard, J.; Adhikari, N.K.; Hladunewich, M.; Richardson, R.M.; James, M.T.; Walsh, M.W.; House, A.A.; et al. Timing the initiation of renal replacement therapy for acute kidney injury in Canadian intensive care units: A multicentre observational study. Can. J. Anesth./J. Can. d'anesthésie 2012, 59, 861-870. [CrossRef]

154. Karvellas, C.J.; Farhat, M.R.; Sajjad, I.; Mogensen, S.S.; Leung, A.A.; Wald, R.; Bagshaw, S.M. A comparison of early versus late initiation of renal replacement therapy in critically ill patients with acute kidney injury: A systematic review and meta-analysis. Crit. Care 2011, 15, R72. [CrossRef]

155. Clec'h, C.; Darmon, M.; Lautrette, A.; Chemouni, F.; Azoulay, E.; Schwebel, C.; Dumenil, A.S.; Garrouste-Orgeas, M.; Goldgran-Toledano, D.; Cohen, Y.; et al. Efficacy of renal replacement therapy in critically ill patients: A propensity analysis. Crit. Care 2012, 16, R236. [CrossRef]

156. Elseviers, M.M.; Lins, R.L.; Van der Niepen, P.; Hoste, E.; Malbrain, M.L.; Damas, P.; Devriendt, J. SHARF investigators. Renal replacement therapy is an independent risk factor for mortality in critically ill patients with acute kidney injury. Crit. Care 2010, 14, R221. [CrossRef] [PubMed]

157. Zarbock, A.; Kellum, J.A.; Schmidt, C.; Van Aken, H.; Wempe, C.; Pavenstädt, H.; Boanta, A.; Gerß, J.; Meersch, M. Effect of Early vs Delayed Initiation of Renal Replacement Therapy on Mortality in Critically Ill Patients With Acute Kidney Injury. JAMA 2016, 315, 2190. [CrossRef]

158. Gaudry, S.; Hajage, D.; Schortgen, F.; Martin-Lefevre, L.; Pons, B.; Boulet, E.; Boyer, A.; Chevrel, G.; Lerolle, N.; Carpentier, D.; et al. Initiation Strategies for Renal-Replacement Therapy in the Intensive Care Unit. N. Engl. J. Med. 2016, 375, 122-133. [CrossRef]

159. Barbar, S.D.; Clere-Jehl, R.; Bourredjem, A.; Hernu, R.; Montini, F.; Bruyère, R.; Lebert, C.; Bohé, J.; Badie, J.; Eraldi, J.P.; et al. Timing of Renal-Replacement Therapy in Patients with Acute Kidney Injury and Sepsis. N. Engl. J. Med. 2018, 379, 1431-1442. [CrossRef] [PubMed] 
160. STARRT-AKI Investigators. STandard versus Accelerated initiation of Renal Replacement Therapy in Acute Kidney Injury: Study Protocol for a Multi-National, Multi-Center, Randomized Controlled Trial. Can. J. Kidney Health Dis. 2019, 6, 205435811985293. [CrossRef] [PubMed]

161. Gaudry, S.; Hajage, D.; Martin-Lefevre, L.; Louis, G.; Moschietto, S.; Titeca-Beauport, D.; La Combe, B.; Pons, B.; de Prost, N.; Besset, S.; et al. The Artificial Kidney Initiation in Kidney Injury 2 (AKIKI2): Study protocol for a randomized controlled trial. Trials 2019, 20, 726. [CrossRef]

162. Combes, A.; Bréchot, N.; Amour, J.; Cozic, N.; Lebreton, G.; Guidon, C.; Zogheib, E.; Thiranos, J.C.; Rigal, J.C.; Bastien, O.; et al. Early High-Volume Hemofiltration versus Standard Care for Post-Cardiac Surgery Shock. The HEROICS Study. Am. J. Respir. Crit. Care Med. 2015, 192, 1179-1190. [CrossRef]

163. Karakala, N.; Tolwani, A.J. Timing of Renal Replacement Therapy for Acute Kidney Injury. J. Intensive Care Med. 2019, 34, 94-103. [CrossRef]

164. Srisawat, N.; Sileanu, F.E.; Murugan, R.; Bellomod, R.; Calzavacca, P.; Cartin-Ceba, R.; Cruz, D.; Finn, J.; Hoste, E.E.; Kashani, K.; et al. Variation in Risk and Mortality of Acute Kidney Injury in Critically Ill Patients: A Multicenter Study. Am. J. Nephrol. 2015, 41, 81-88. [CrossRef]

165. Park, S.; Cho, H.; Park, S.; Lee, S.; Kim, K.; Yoon, H.J.; Park, J.; Choi, Y.; Lee, S.; Kim, J.H.; et al. Simple Postoperative AKI Risk (SPARK) Classification before Noncardiac Surgery: A Prediction Index Development Study with External Validation. J. Am. Soc. Nephrol. 2019, 30, 170-181. [CrossRef]

166. Bedford, M.; Stevens, P.; Coulton, S.; Billings, J.; Farr, M.; Wheeler, T.; Kalli, M.; Mottishaw, T.; Farmer, C. Development of risk models for the prediction of new or worsening acute kidney injury on or during hospital admission: A cohort and nested study. Health Serv. Deliv. Res. 2016, 4, 1-160. [CrossRef]

167. Kashani, K.; Rosner, M.H.; Haase, M.; Lewington, A.J.P.; O’Donoghue, D.J.; Wilson, F.P.; Nadim, M.K.; Silver, S.A.; Zarbock, A.; Ostermann, M.; et al. Quality Improvement Goals for Acute Kidney Injury. Clin. J. Am. Soc. Nephrol. 2019, 14, 941-953. [CrossRef] [PubMed]

168. Jha, V.; Parameswaran, S. Community-acquired acute kidney injury in tropical countries. Nat. Rev. Nephrol. 2013, 9, 278-290. [CrossRef] [PubMed]

169. Sawhney, S.; Fluck, N.; Fraser, S.D.; Marks, A.; Prescott, G.J.; Roderick, P.J.; Black, C. KDIGO-based acute kidney injury criteria operate differently in hospitals and the community-Findings from a large population cohort. Nephrol. Dial. Transplant. 2016, 31, 922-929. [CrossRef] [PubMed]

170. Wang, Y.; Wang, J.; Su, T.; Qu, Z.; Zhao, M.; Yang, L. ISN AKF 0by25 China Consortium. Community-Acquired Acute Kidney Injury: A Nationwide Survey in China. Am. J. Kidney Dis. 2017, 69, 647-657. [CrossRef]

171. Emmett, L.; Tollitt, J.; McCorkindale, S.; Sinha, S.; Poulikakos, D. The Evidence of Acute Kidney Injury in the Community and for Primary Care Interventions. Nephron 2017, 136, 202-210. [CrossRef]

172. Malhotra, R.; Kashani, K.B.; Macedo, E.; Kim, J.; Bouchard, J.; Wynn, S.; Li, G.; Ohno-Machado, L.; Mehta, R. A risk prediction score for acute kidney injury in the intensive care unit. Nephrol. Dial. Transplant. 2017, 32, 814-822. [CrossRef]

173. Göcze, I.; Jauch, D.; Götz, M.; Kennedy, P.; Jung, B.; Zeman, F.; Gnewuch, C.; Graf, B.M.; Gnann, W.; Banas, B.; et al. Biomarker-guided Intervention to Prevent Acute Kidney Injury After Major Surgery. Ann. Surg. 2018, 267, 1013-1020. [CrossRef]

174. Joannidis, M.; Druml, W.; Forni, L.G.; Groeneveld, A.B.J.; Honore, P.M.; Hoste, E.; Ostermann, M.; Oudemans-van Straaten, H.M.; Schetz, M. Prevention of acute kidney injury and protection of renal function in the intensive care unit: Update 2017. Intensive Care Med. 2017, 43, 730-749. [CrossRef]

175. Hodgson, L.E.; Selby, N.; Huang, T.-M.; Forni, L.G. The Role of Risk Prediction Models in Prevention and Management of AKI. Semin. Nephrol. 2019, 39, 421-430. [CrossRef]

176. Karsanji, D.J.; Pannu, N.; Manns, B.J.; Hemmelgarn, B.R.; Tan, Z.; Jindal, K.; Scott-Douglas, N.; James, M.T. Disparity between Nephrologists' Opinions and Contemporary Practices for Community Follow-Up after AKI Hospitalization. Clin. J. Am. Soc. Nephrol. 2017, 12, 1753-1761. [CrossRef] [PubMed]

177. Silver, S.A.; Siew, E.D. Follow-up Care in Acute Kidney Injury: Lost in Transition. Adv. Chronic Kidney Dis. 2017, 24, 246-252. [CrossRef] [PubMed]

178. Saran, R.; Li, Y.; Robinson, B.; Abbott, K.C.; Agodoa, L.Y.; Ayanian, J.; Bragg-Gresham, J.; Balkrishnan, R.; Chen, J.L.; Cope, E.; et al. US Renal Data System 2015 Annual Data Report: Epidemiology of Kidney Disease in the United States. Am. J. Kidney Dis. 2016, 67, A7-A8. [CrossRef] [PubMed] 
179. Siew, E.D.; Peterson, J.F.; Eden, S.K.; Hung, A.M.; Speroff, T.; Ikizler, T.A.; Matheny, M.E. Outpatient Nephrology Referral Rates after Acute Kidney Injury. J. Am. Soc. Nephrol. 2012, 23, 305-312. [CrossRef]

180. Harel, Z.; Wald, R.; Bargman, J.M.; Mamdani, M.; Etchells, E.; Garg, A.X.; Ray, J.G.; Luo, J.; Li, P.; Quinn, R.R.; et al. Nephrologist follow-up improves all-cause mortality of severe acute kidney injury survivors. Kidney Int. 2013, 83, 901-908. [CrossRef]

181. Fortrie, G.; de Geus, H.R.H.; Betjes, M.G.H. The aftermath of acute kidney injury: A narrative review of long-term mortality and renal function. Crit. Care 2019, 23, 24. [CrossRef]

(C) 2020 by the authors. Licensee MDPI, Basel, Switzerland. This article is an open access article distributed under the terms and conditions of the Creative Commons Attribution (CC BY) license (http://creativecommons.org/licenses/by/4.0/). 